\title{
PENGELOLAAN KELAS RENDAH DI SD AMALIAH CIAWI BOGOR
}

\section{MANAGEMENT OF LOWER GRADE AT AMALIAH ELEMENTARY SCHOOL CIAWI BOGOR}

\author{
RR Aliyyah ${ }^{1 a}$ dan 0 Abdurakhman ${ }^{1}$ \\ ${ }^{1}$ Program Studi Pendidikan Guru Sekolah Dasar, Fakultas Keguruan dan Ilmu Pendidikan, \\ Universitas Djuanda Bogor, Jl. Tol Ciawi No. 1 Kotak Pos 35 Ciawi Bogor 16720 \\ a Korespondensi: Rusi Rusmiati Aliyyah, Email: rusi_rusmiati84@yahoo.co.id \\ (Diterima: 15-05-2016; Ditelaah: 15-05-2016; Disetujui: 20-07-2016)
}

\begin{abstract}
This research is aimed at finding the strategy of low class management at planning, managing and controlling stages at Amaliah Elementary School Ciawi Bogor. This research uses qualitative method using a case study approach. The data collection procedures were carried out through observation, interviews and documentation study. The validity test was carried out through the additional time of research, finding the data similarity, the seriousness of the research, data triangulation, discussion, references and making detailed description. The conclusion of the research at the planning stage is started by making lesson plans, annual and semester program. The classroom management was carried out through the arrangement of the students and better classroom facilities, classroom physical condition, students' social, emotional condition and the expertise of the teachers in managing classroom as the key the success of the fun teaching process. While the controlling stake was carried out through classroom monitoring and supervision, which was done every day by home class teachers for all students and then given the reward and punishment model.
\end{abstract}

Keywords: controlling, managing classroom, plannig.

\begin{abstract}
ABSTRAK
Penelitian bertujuan mengetahui strategi pengelolaan kelas rendah pada perencanaan, pengelolaan dan pengawasan SD Amaliah Ciawi Bogor. Penelitian ini menggunakan metode kualitatif dengan pendekatan studi kasus. Prosedur pengumpulan data dilakukan melalui observasi, wawancara dan studi dokumentasi. Pengujian keabsahan data dilakukan melalui cara memperpanjang waktu penelitian, mencari siklus kesamaan data, ketekunan penelitian, triangulasi, diskusi, mencari kecukupan referensi dan membuat uraian rinci. Kesimpulan penelitian tahap perencanaan dimulai dari membuat RPP, program tahunan, dan program semester. Pengelolaan kelas dilakukan melalui upaya pengaturan siswa dan fasilitas kelas yang baik, faktor kondisi fisik ruang kelas, sosio-emosional siswa dan kemahiran guru dalam pengorganisasian kelas menjadi kunci terciptanya keberhasilan tujuan pembelajaran yang menyenangkan. Sementara pengawasan dilakukan melalui monitoring atau supervisi kelas yang dilakukan setiap hari oleh guru kelas kepada semua siswa, untuk kemudian diberikan reward and punishment.
\end{abstract}

Kata kunci: pengelolaan kelas, pengawasan, perencanaan.

Aliyyah RR dan O Abdurakhman. 2016. Pengelolaan kelas rendah di SD Amaliah Ciawi Bogor. Jurnal Sosial Humaniora 7(2): 81-95. 


\section{PENDAHULUAN}

Memasuki era globalisasi di abad 21 diperlukan paradigma baru dalam sistem pendidikan dunia dalam rangka mencerdaskan umat manusia dan memelihara persaudaraan. Pemikiran tersebut telah disadari oleh UNESCO yang merekomendasikan "empat pilar pembelajaran" untuk memasuki era globalisasi yaitu program pembelajaran yang diberikan hendaknya memberikan kesadaran kepada masyarakat sehingga mau dan mampu belajar learning to know of learning learn. Bahan belajar yang dipilih hendaknya mampu memberikan suatu pekerjaan yang alternatif kepada peserta didiknya learning to do, dan mampu memberikan motivasi untuk hidup dalam era sekarang dan memiliki orientasi hidup ke masa depan learning to be.

Pembelajaran tidak cukup hanya diberikan dalam bentuk keterampilan untuk dirinya sendiri, tetapi juga keterampilan untuk hidup bertetangga, bermasyarakat, berbangsa dan hidup dalam pergaulan antar bangsa dengan semangat kesamaan dan kesejajaran.

Dibandingkan dengan sektor atau organisasi lain, terutama organisasi yang berorientasi bisnis, pengelolaan sektor pendidikan relatif tertinggal, meskipun persoalan dan tantangan yang dihadapi relatif sama yaitu semakin meningkatnya tuntutan sistem. Subsistem yang selama ini belum begitu ditangani adalah subsistem manajemen pengelolaan.

Bahkan, krisis kependidikan yang dihadapi dan dirasakan saat ini berkisar pada krisis manajemen. Di samping faktor lain, faktor pengelolaan akan sangat menentukan produktivitas dan efektivitas lembaga pendidikan. Pendidikan sebagai sebuah sistem tidak akan mampu menghasilkan output dan outcome yang berkualitas, apabila proses pendidikan tersebut tidak dikelola dengan baik.

Masalah yang dihadapi guru, baik pemula maupun yang sudah berpengalaman adalah masalah pengelolaan kelas. Pengelolaan kelas adalah masalah tingkah laku yang kompleks, dan guru menggunakannya untuk menciptakan serta mempertahankan kondisi kelas sedemikian rupa sehingga anak didik dapat mencapai tujuan pengajaran secara efisien dan memungkinkan mereka dapat belajar (Djamarah 2006).

Keberhasilan siswa dalam belajar sangat ditentukan oleh strategi pembelajaran yang dilakukan oleh guru. Guru dituntut untuk memahami komponen-komponen dasar dalam melaksanakan kegiatan pembelajaran di dalam kelas. Dengan demikian, guru dituntut untuk paham tentang filosofi dari mengajar dan belajar itu sendiri. Mengajar tidak hanya sekedar mentransfer ilmu pengetahuan, tetapi juga sejumlah yang akan menjadi kepemilikan siswa.

Pengaturan metode, strategi, dan kelengkapan dalam pengajaran adalah bagian dari kegiatan pengelolaan pembelajaran yang harus dilakukan oleh guru. Untuk mewujudkan pengelolaan kelas di Sekolah Dasar, lingkungan fisik yang menguntungkan dan memenuhi syarat akan mendukung meningkatnya intensitas pembelajaran siswa dan mempunyai pengaruh positif terhadap pencapaian tujuan pengajaran.

Pengelolaan kelas di Sekolah Dasar tidak hanya pengaturan belajar, fasilitas fisik dan rutinitas, tetapi menyiapkan kondisi kelas dan lingkungan sekolah agar tercipta kenyamanan dan suasana belajar yang efektif. Oleh karena itu, sekolah dan kelas perlu dikelola secara baik dan menciptakan iklim belajar yang menunjang.

Banyaknya Sekolah Dasar (SD) yang belum mempunyai strategi dalam pengelolaan kelas yang baik, membuat peneliti tertarik untuk meneliti tentang pengelolaan kelas rendah di SD Amaliah Ciawi Bogor sebagai sebuah terobosan guna membantu menginformasikan strategi pengelolaan kelas yang mampu membuat anak-anak nyaman dalam proses pembelajaran, khususnya kelas satu sampai dengan kelas tiga SD. 


\section{MATERI DAN METODE}

\section{Perencaan Pengelolaan Kelas Rendah}

Planning involves defining the organization's goals, establishing strategies for achieving those goals, and developing plans to integrate and coordinate work activities. It's concerned with both ends (what) and means (how) (Robbins and Coulter 2012). Perencanaan membahas tentang definisi tujuan organisasi, penetapan strategi untuk mencapai tujuan, mengembangkan rencana untuk mengintegrasikan, dan mengkoordinasikan kegiatan kerja. Hal ini berkaitan dengan kedua kata (apa) dan cara (bagaimana). Planning is a management function that involves defining goals, establishing strategies for achieving those goals, and developing plants to integrate and coordinate activities (Robbins and Coulter 2009). Perencanaan adalah fungsi manajemen yang melibatkan tujuan mendefinisikan, strategi membangun untuk mencapai tujuan tersebut, dan menumbuhkan perkembangan untuk mengintegrasikan serta mengkoordinasikan kegiatan.

Jones and George (2009) juga menyebutkan planning is a process that managers use to identify and select appropriate goals and courses of action. The three steps in the planning process are:(1) deciding which goals the organization will pursue, (2) deciding what courses of action to adopt to attain those goals, and (3) deciding how to allocate organizational resources to attain those goals. Perencanaan adalah proses memilih untuk mengidentifikasi dan memilih tujuan yang tepat dan arah tindakan. Tiga langkah dalam proses perencanaan ialah (1) memutuskan tujuan organisasi, (2) memutuskan apa program tindakan untuk mengadopsi tercapainya tujuan tersebut, dan (3) memutuskan bagaimana mengalokasikan sumber daya organisasi untuk mencapai tujuan tersebut.

Pengelolaan kelas merupakan usaha sadar untuk mengatur kegiatan proses pembelajaran secara sistematis. Usaha sadar itu mengarah pada penyiapan bahan belajar, penyiapan sarana dan alat peraga, pengaturan ruang belajar, mewujudkan situasi atau kondisi proses pembelajaran, dan pengaturan waktu sehingga pembelajaran berjalan dengan baik dan tujuan kurikuler dapat tercapai (Dirjen PUOD dan Dirjen Dikdasmen 1996). Pengelolaan kelas adalah suatu upaya memperdayakan potensi kelas yang ada seoptimal mungkin untuk mendukung proses interaksi edukatif mencapai tujuan pembelajaran (Djamarah 2006). Selain itun, pengelolaan kelas adalah segala usaha yang diarahkan untuk mewujudkan suasana belajar mengajar yang efektif dan menyenangkan, serta dapat memotivasi siswa untuk belajar dengan baik sesuai dengan kemampuan (Tim Dosen Adpen UPI 2010).

Berdasarkan pendapat para pakar tersebut di atas, maka dapat disintesiskan bahwa yang dimaksud dengan perencanaan pengelolaan kelas rendah adalah sebuah kegiatan yang harus dilaksanakan oleh seseorang atau organisasi di masa yang akan datang dengan memperhatikan pertanyaan apa, siapa, bagaimana, dimana, dan kapan kegiatan guru untuk menumbuhkan dan mempertahankan organisasi kelas yang efektif, yaitu meliputi tujuan pengajaran, pengaturan waktu, pengaturan ruangan, dan peralatan serta pengelompokan siswa dalam belajar pada kelas satu, dua, dan tiga SD.

\section{Metode dan Prosedur Penelitian}

Penelitian ini menggunakan pendekatan kualitatif, sedangkan metode yang digunakan adalah metode studi kasus. Pendekatan kualitatif dengan metode studi kasus digunakan untuk mengkaji dan menjawab permasalahan serta untuk memperoleh makna yang lebih mendalam tentang pengelolaan kelas rendah pada Sekolah Dasar Amaliah Ciawi Bogor.

Penelitian kualitatif merupakan metodemetode untuk mengeksplorasi dan memahami makna yang dianggap berasal dari masalah sosial atau kemanusiaan. Proses penelitian kualitatif ini melibatkan upaya-upaya penting seperti mengajukan 
pertanyaan-pertanyaan dan prosedurprosedur, mengumpulkan data yang spesifik dari para partisipan, menganalisis data secara induktif mulai dari tema-tema yang khusus ke tema-tema yang umum, dan menafsirkan makna data. Laporan akhir untuk penelitian ini memiliki struktur atau kerangka yang fleksibel. Siapun yang terlibat dalam bentuk penelitian ini harus menerapkan cara pandang penelitian yang bergaya induktif, berfokus terhadap makna individual, dan menerjemahkan kompleksitas suatu persoalan (Creswell 2010).

Pemilihan metode dengan studi kasus karena studi kasus merupakan suatu inkuiri empiris yang menyelidiki fenomena di dalam konteks kehidupan nyata, bilamana batasbatas antara fenomena dan konteks tidak tampak dengan tegas dan multisumber bukti dimanfaatkan (Yin 2004). Adapun Woodside (2010) mengatakan bahwa case study research is an inquiry that focuses on describing, understanding, predicting, and/or controlling the individual (i.e., process, animal, person, household, organization, group, industry, culture, or nationality). This definition is intentionally broader than the definition that Yin (1944) proposes: A case study is an empirical inquiry that investigates a contemporary phenomenon within its real life context, especially when the boundaries between phenomenon and context are not clearly evident.

$\begin{array}{rrrr}\text { Penelitian } & \text { studi } & \text { kasus adalah } \\ \text { penyelidikan } & \text { yang } & \text { berfokus } & \text { pada }\end{array}$ menjelaskan, memahami, memprediksi, dan/atau mengendalikan individu (proses, binatang, orang, rumah tangga, organisasi, kelompok, industri, kebudayaan, atau kebangsaan). Definisi ini sengaja lebih luas daripada definisi yang Yin (1944) usulkan yakni sebuah studi kasus adalah penyelidikan empiris yang menyelidiki fenomena kontemporer dalam konteks kehidupan nyata, terutama ketika batasbatas antara fenomena dan konteks tidak jelas.

\section{Data dan Sumber Data}

\section{Data}

Data penelitian ini menggunakan multisumber bukti (data). Sebagaimana disampaikan oleh Yin (2004) bahwa data untuk keperluan studi kasus bisa berasal dari enam sumber, yaitu dokumen, rekaman arsip, wawancara, pengamatan langsung, observasi partisipan, dan perangkatperangkat fisik.

Data yang dikumpulkan dalam penelitian ini berbentuk dokumen berupa bahan-bahan tertulis seperti buku pedoman, profil sekolah, absen, laporan, dan sebagainya yang didapat dari SD Amaliah Ciawi Bogor. Data juga meliputi tempat dan peristiwa sebagai sumber data tambahan yang dilakukan melalui observasi langsung terhadap tempat dan peristiwa yang berkaitan dengan pengelolaan kelas rendah pada SD Amaliah Ciawi Bogor.

\section{Sumber Data}

Menurut Lofland dan Lofland dalam bukunya Moleong (2006), sumber data utama dalam penelitian kualitatif ialah kata-kata dan tindakan, selebihnya adalah data tambahan seperti dokumen dan lain-lain. Sesuai dengan data yang dikumpulkan, maka sumber data dalam penelitian ini adalah kepala sekolah, wakil kepala sekolah, guru, siswa, yayasan, pengawas, UPT Pendidikan Kecamatan Ciawi, komite, dan orang tua murid yang terlibat langsung dalam pengelolaan kelas rendah pada SD Amaliah Ciawi Bogor.

\section{Teknik dan Prosedur Pengumpulan Data}

Sesuai dengan jenis pendekatan yang digunakan, teknik yang dipergunakan dalam pengumpulan data pada penelitian kualitatif ini adalah observasi, wawancara, studi dokumentasi, dan rekaman arsip. Keempat teknik pengumpulan data tersebut dalam penggunaannya dapat saling melengkapi dan menunjang sehingga dapat diperoleh informasi yang diperlukan (Silverman 1994). 


\section{Observasi}

Observasi atau pengamatan dimanfaatkan sebesar-besarnya dalam penelitian kualitatif karena (1) teknik observasi atau pengamatan didasarkan atas pengalaman secara langsung, (2) teknik pengamatan juga memungkinkan melihat dan mengamati sendiri, kemudian mencatat perilaku dan kejadian sebagaimana yang terjadi pada keadaan sebenarnya, (3) observasi atau pengamatan memungkinkan peneliti mencatat peristiwa dalam situasi yang berkaitan dengan pengetahuan proposisional maupun pengetahuan yang langsung diperoleh dari data, (4) jika terdapat kekeliruan dalam wawancara, maka observasi atau pengamatan dapat dilakukan untuk mengecek kepercayaan data yang keliru tadi, (5) teknik pengamatan memungkinkan peneliti mampu memahami situasi-situasi yang rumit, (6) dalam kasuskasus tertentu, teknik komunikasi lainnya tidak dimungkinkan, pengamatan dapat menjadi alat yang sangat bermanfaat (Moleong 2006).

Observasi dilakukan dengan mengamati dan mendengarkan guru, siswa, orang tua murid, kepala sekolah, wakil kepala sekolah SD Amaliah Ciawi Bogor tentang hal-hal yang berkaitan dengan pengelolaan kelas rendah. Peneliti juga terlibat dalam peran yang beragam mulai dari non partisipan hingga partisipan utuh.

\section{Wawancara}

Wawancara adalah percakapan dengan maksud tertentu. Percakapan itu dilakukan oleh dua pihak, yaitu pewawancara (interviewer) yang mengajukan pertanyaan dan terwawancara (interviewee) yang memberikan jawaban atas pertanyaan itu. Maksud diadakannya wawancara antara lain ialah untuk (1) melakukan konstruksi mengenai orang, kejadian, organisasi, perasaan, motivasi, tuntutan, kepedulian, dan lain-lain kebulatan; (2) merekonstruksi kebulatan-kebulatan demikian sebagai yang alami masa lalu; (3) memproyeksikan kebulatan-kebulatan sebagai yang diharapkan untuk dialami pada masa yang akan datang; (4) memverifikasi, mengubah, dan memperluas informasi yang diperoleh dari orang lain, baik manusia maupun bukan manusia (triangulasi); (5) memverifikasi, mengubah, dan memperluas konstruksi yang dikembangkan oleh peneliti sebagai pengecekan anggota (Moleong 2006).

Agar memudahkan peneliti dalam mengumpulkan data, peneliti telah menyusun pedoman wawancara sesuai dengan permasalahan penelitian, yakni data yang berkaitan dengan pengelolaan kelas rendah SD Amaliah Ciawi Bogor.

\section{Studi Dokumentasi}

Metode dokumenter adalah salah satu metode pengumpulan data yang digunakan dalam metodologi penelitian sosial. Pada intinya, metode dokumenter adalah metode yang digunakan untuk menelusuri data historis. Sebagian besar data yang tersedia adalah berbentuk surat-surat, catatan harian, cenderamata, laporan, dan sebagainya. Sifat utama dari data ini tidak terbatas pada ruang dan waktu sehingga memberi peluang kepada peneliti untuk mengetahui hal-hal yang pernah terjadi di waktu silam. Kumpulan data bentuk tulisan ini disebut dokumen dalam arti luas termasuk monumen, artefak, foto, tape, mikrofon, disc, harddisk, flashdisk, dan sebagainya (Bungin 2010).

Studi dokumentasi sangat penting sebagai produk nyata yang dapat memberikan gambaran lebih jelas mengenai pengelolaan kelas rendah SD Amaliah Ciawi Bogor dan juga sekaligus digunakan sebagai bahan triangulasi dan member cek terhadap kebenaran dan keterangan responden.

\section{Rekaman Arsip}

Rekaman arsip dapat berupa rekaman proses pembelajaran dalam kelas atau rekaman-rekaman pribadi lainnya seperti buku, agenda, dan lain-lain.

\section{Prosedur Analisis Data}

Adapun prosedur analisis data yang digunakan dalam penelitian ini sebagaimana 
dikemukakan oleh Miles dan Huberman (1992) bahwa prosedur analisis data terdiri dari tiga alur kegiatan yang terjadi secara bersamaan yaitu reduksi data, penyajian data, dan penarikan kesimpulan atau verifikasi.

\section{Reduksi Data}

Reduksi data merupakan sebuah proses pemilihan, pemusatan perhatian pada penyederhanaan, pengabstrakan, dan transformasi data kasar yang muncul dari catatan-catatan tertulis di lapangan. Reduksi data dilakukan untuk menelaah secara keseluruhan data yang dihimpun dari lapangan sehingga dapat ditemukan hal-hal pokok dari objek yang diteliti tersebut. Reduksi data berlangsung selama penelitian sampai laporan akhir tersusun. Data yang direduksi adalah data dari segala sumber, dipilah data yang diperlukan dan tidak diperlukan. Kegiatan yang dilakukan antara lain:

a. mengumpulkan data dan informasi dari hasil catatan, hasil wawancara, dan hasil pengamatan;

b. mencari inti atau pokok-pokok yang dianggap penting dari setiap aspek temuan penelitian ini.

\section{Penyajian Data}

Penyajian data merupakan perangkuman terhadap temuan penelitian dalam susunan yang sistematis untuk mengetahui perencanaan, penggerakan, dan pengawasan pendidikan berbasis karakter dan teknologi. Alur ini dilakukan selama penelitian sampai tersusunnya laporan. Kegiatan yang dilakukan dalam tahapan ini antara lain:

a. membuat rangkuman secara deskriptif dan sistematis sehingga tema sentral dapat diketahui dengan mudah;

b. member maksud pada setiap rangkuman tersebut dengan memperhatikan kesesuaian dengan materi penelitian.

\section{Verifikasi}

Verifikasi merupakan tahap penarikan kesimpulan dari kumpulan makna setiap kategori. Adapun langkah-langkahnya antara lain:

a. menguji kesimpulan yang telah diambil dengan membandingkan teori-teori yang dikemukakan, terutana teori yang relevan;

b. melakukan proses member cek atau proses pengecekan ulang mulai dari pelaksanaannya, prasurvei, wawancara inti, pengamatan dari data, dan info yang sudah dikumpulkan;

c. membuat kesimpulan umum untuk dilaporkan sebagai hasil dari penelitian yang sudah dilakukan ini.

\section{Pemeriksaan Keabsahan Data}

Untuk menetapkan keabsahan (trustworthiness) data diperlukan teknik pemeriksaan. Pelaksanaan teknik pemeriksaan didasarkan atas sejumlah kriteria tertentu. Ada empat kriteria yang akan digunakan dalam penelitian ini, yaitu derajat kepercayaan (credibility), keteralihan (transferability), kebergantungan (dependability), dan kepastian (comfirmability) (Moleong 2006).

\section{HASIL DAN PEMBAHASAN}

\section{Hasil}

\section{Perencanaan Pengelolaan Kelas Rendah di SD Amaliah Ciawi Bogor}

Berdasarkan temuan yang didapatkan selama pengambilan data, perencanaan pengelolaan kelas rendah pada SD Amaliah Ciawi Bogor dilakukan mulai dari pembuatan RPP, silabus, program tahunan, semester, dan KKM yang menggunakan KTSP sehingga materinya berbentuk tematik sesuai kalender akademik. Hal tersebut memudahkan guru untuk merealisasikan berbagai program yang akan dilakukan di kelas sesuai dengan jadwal yang sudah 
dibuat. Berbagai administrasi guru tersebut memberikan gambaran tentang apa yang harus dilakukan guru dalam pengelolaan kelas rendah yang baik sehingga tidak keluar dari peraturan yang sudah disepakati oleh stakeholders pendidikan, baik dalam rapat kerja (raker) bersama yayasan dan dewan guru maupun melalui forum rapat awal tahun dengan orang tua murid.

Perencanaan pengelolaan kelas rendah yang baik juga diawali dengan komunikasi yang terjadi antara orang tua dengan wali kelas yang simultan dan komunikatif. Hal tersebut mudah dilakukan karena sekolah memfasilitasi buku penghubung sebagai bentuk komunikasi dengan orang tua terkait kegiatan yang akan dan sudah dilakukan serta Pekerjaan Rumah (PR) yang harus diselesaikan oleh putra-putrinya di rumah. Selain itu, ada buku Bimbingan dan Konseling yang senantiasa menjadi penghubung antara guru dengan orang tua murid untuk memberikan informasi terkait apa yang sudah terjadi dengan putraputrinya di kelas selama proses pembelajaran. Buku penghubung dan BK tersebut menjadi penting adanya sebagai sebuah rencana guna pengaplikasian pengelolaan kelas yang baik. Dengan terjalinnya komunikasi yang baik antara guru dengan orang tua murid diharapkan akan lebih memberikan kemudahan guru dalam upaya pengelolaan kelasnya.

Adapun yang menjadi salah satu hal yang sangat unik dari perencanaan pengelolaan kelas rendah di SD Amaliah Ciawi Bogor adalah bahwa ide pertama kali untuk memunculkan sebuah program itu senantiasa muncul dari orang tua murid untuk kemudian direalisasikan dalam kegiatan kelas. Rapat orang tua yang kontinu dan per kelas memungkinkan dihadirinya oleh kepala sekolah dan struktural sekolah pada setiap kelas. Peran orang tua murid dalam memberikan kontribusi berupa ide dan pendapat tersebut senantiasa mewarnai proses pembelajaran terutama dalam pengelompokkan kelas rendah di SD Amaliah Ciawi Bogor. Peran orang tua di SD Amaliah Ciawi Bogor sangat besar dan senantiasa berjalan sinergis dengan program yang sudah dibuat oleh sekolah ataupun kelas. Komunikasi antara orang tua, siswa, dan guru terjalin dengan baik pada setiap saat melalui berbagai media dan perangkat yang sudah disiapkan oleh sekolah dan guru kelas.

Selanjutnya, hasil pengamatan peneliti selama di lapangan, jika dilihat berdasarkan waktunya, perencanaan pengelolaan kelas rendah di SD Amaliah Ciawi Bogor ada yang dibuat berdasarkan waktu jangka pendek, jangka menengah, dan jangka panjang. Dengan dibuat perencanaan berdasarkan ketiga waktu tersebut, maka akan sangat memudahkan lembaga untuk memperoleh hasil sesuai dengan yang diharapkan.

\section{Pengelolaan Suasana Kelas Rendah di SD Amaliah Ciawi Bogor}

Kegiatan pengelolaan kelas rendah pada SD Amaliah Ciawi Bogor terdiri dari pengelolaan siswa yang merupakan aset sehingga harus dibina dan dididik menjadi insan kamil sesuai dengan amanah Undang-undang Sistem Pendidikan Nasional. Dalam upaya pengaturan siswa pada kelas 1, 2, dan 3 di SD Amaliah Ciawi Bogor dilakukan mulai dengan sikap guru yang senantiasa memberikan sikap tenang pada saat siswa datang dan memasuki gerbang sekolah. Guru menyambut dengan senyum yang ramah dan percaya diri pada setiap hari proses pembelajaran di sekolah. Pemberian senyum, sapa, dan salam senantiasa guru berikan dalam setiap kesempatan kepada para siswa. Pada masa awal pertemuan tahun ajaran baru, guru kelas 1, 2, dan 3 senantiasa memberikan waktu kepada para siswa untuk dapat memperkenalkan diri mereka masing-masing di kelas agar terjadi komunikasi yang baik di antara teman kelas. Setelah terjadi komunikasi yang baik di kelas, baru kemudian pada hari-hari selanjutnya guru memulai memberikan materi pelajaran disertai dengan peraturan dan tata tertib yang sudah disepakati bersama antara guru dengan orang tua dan siswa pada kelas dua dan tiga untuk secara seksama melakukan apa yang seharusnya siswa lakukan selama di kelas. Siswa kelas 
satu belum diperkenankan untuk diajak diskusi terkait peraturan mengingat usia mereka masih belum memadai untuk diajak diskusi kelas. Sebelum proses pembelajaran dimulai, guru kelas 1, 2, dan 3 senantiasa menjelaskan bagaimana tata cara menyampaikan pendapat, berbicara, dan bertanya yang baik dalam forum diskusi kelas. Hal tersebut dilakukan agar menumbuhkan sikap disiplin dari diri masing-masing siswa kelas 1, 2, dan 3 SD Amaliah Ciawi Bogor. Sementara itu, pengaturan tempat duduk siswa disesuaikan dengan materi yang akan diberikan oleh guru sehingga sangat dimungkinkan tempat duduk siswa akan berubah dalam setiap minggunya.

Adapun faktor yang dapat mempengaruhi berhasilnya pengelolaan kelas yang baik pada SD Amaliah Ciawi Bogor di antaranya karena faktor fisik, sosio-emosional, dan organisasional. Kondisi fisik mulai dari ruangan kelas yang sesuai dengan peraturan BSNP tentang sarana dan prasarana sangat memungkinkan guru kelas untuk dapat melakukan pengaturan kelas dan tempat duduk yang baik untuk siswanya, serta memungkinkan guru kelas untuk dapat mengatur semua barang siswa dalam loker yang tempat lain yang baik.

Kondisi sosio-emosional salah satunya terlihat ketika guru mulai melakukan aksinya sebagai leader (pemimpin) di kelasnya. Gaya kepemimpinan guru yang senantiasa demokratis menjadi ciri guru kelas rendah di SD Amaliah Ciawi Bogor. Kelantangan suara, sikap santun, dan ramah yang senantiasa dilakukan oleh guru kelas menjadi bagian penting dalam diri guru pada sekolah tersebut. Sementara itu, secara organisasional, kondisi kelas rendah di SD Amaliah Ciawi Bogor terlihat dengan baik pada saat guru sedang memberlakukan kedisiplinan kelas kepada para siswa, yakni guru kelas akan memberikan reward dan punishment kepada setiap siswa sesuai dengan tata tertib yang sudah disepakati sebelumnya pada saat pertama masuk kelas pada tahun ajaran baru. Selain itu, pada saat guru sedang menyelesaikan masalah antarsiswa di kelas, guru senantiasa memberikan solusi secara organisatoris dan jelas sehingga membuat semua siswa memahami akan hakikat sebuah permasalahan dan mampu membedakan mana yang benar dan salah dalam kasus tersebut. Hal lain yang dapat peneliti lihat adalah pada saat terjadi masalah dalam diri guru kelas dan kemudian berhalangan hadir ke kelas untuk memberikan materi pembelajaran di kelas, maka kepala sekolah akan segera memberikan mandat kepada guru piket untuk menjadi pengganti guru kelas tersebut. Dalam proses pemberian materi dalam kegiatan pembelajaran di dalam kelas, guru piket tersebut seperti sudah terbiasa masuk kelas rendah dan menjadi guru kelas pada kelas yang guru kelasnya tidak dapat hadir. Selain itu, peneliti juga melihat keadaan yang terorganisir pada saat pelaksanaan kegiatan upacara bendera hari Senin. Semua siswa kelas 2 dan 3 mengikuti kegiatan upacara bendera secara disiplin dan khusu. Meskipun usia anak kelas 2 dan 3 baru sekitar tujuh hingga sembilan tahun, namun mereka sudah mampu menerapkan sifat cinta tanah air yang baik.

\section{Pengawasan Pengelolaan Kelas Rendah di SD Amaliah Ciawi Bogor}

Pengawasan atau supervisi dan monitoring pengelolaan kelas dilakukan setiap hari oleh wali kelas, kepala sekolah, dan orang tua murid. Orang tua senantiasa memantau pelaksanaan pengelolaan kelas rendah di SD Amaliah Ciawi Bogor. Pagi hari setiap anak akan senantiasa diantar oleh orang tuanya sehingga terjadilah komunikasi aktif antara wali kelas dengan orang tua dalam setiap harinya. Wali kelas dan orang tua akan senantiasa memberikan informasi terkait apa yang sudah, sedang, dan harus dilakukan oleh orang tua dan guru terkait tumbuh kembang putra-putrinya sehingga wali kelas relatif lebih dapat mengantisipasi apa yang seharusnya dilakukan pada saat proses pembelajaran di dalam kelas. Misalnya, jika ada anak yang memang sedang susah makan, sulit belajar, senantiasa bangun pagi dan 
selalu menunaikan shalat subuh terlebih dahulu setelah bangun sebelum berangkat ke sekolah atau bahkan ada anak yang sulit mengerjakan PR, orang tua akan menyampaikan permasalahan dan perkembangan putra-putrinya setiap hari kepada wali kelas. Jika pemerintah baru menyampaikan seruan bahwa harus mengantar anak sekolah pada hari pertama anak masuk sekolah oleh orang tuanya, maka pada SD Amaliah Ciawi Bogor, orang tua mengantar anak ke sekolah sudah merupakan rutinitas yang dilakukan sudah sejak lama dan mensosialisasikan hal tersebut pada saat orang tua mendaftarkan, menitipkan anak tersebut ke sekolah, dan akan diperkuat serta dipertegas peraturan tersebut dalam rapat awal tahun pelajaran menjelang masuk sekolah.

Selain hal di atas, evaluasi pengelolaan kelas rendah juga dilakukan melalui pemberian reward dan punishment yang diberikan wali kelas kepada siswa. Pemberian penghargaan tersebut diberikan dalam berbagai kegiatan dan aktivitas siswa, mulai dari siswa masuk kelas sampai dengan keluar kelas. Reward yang diberikan mulai dari pemberian ucapan selamat secara lisan, apresiasi mendalam dalam bentuk tepuk tangan, pemberian nilai, dan berbagai ikon yang dapat membangkitkan serta senantiasa menumbuhkan rasa percaya diri dan dihargai dengan apa yang sudah dilakukan siswa. Ikon penghargaan tersebut dapat berupa gambar bintang, ikon burung garuda yang merupakan hasil kreasi siswa itu sendiri, dan tanda jempol yang kemudian ditempel serta dikumpulkan dalam madding masing-masing anak di kelas. Adapun punishment yang biasa dilakukan oleh guru ialah ketika ada anak yang belum mampu melakukan peraturan dengan benar atau bahkan melanggar suatu peraturan yang sudah disepakati sebelumnya antara anak, guru dan orang tua pada saat proses pembelajaran berlangsung. Pada setiap tahun ajaran baru akan dimulai, guru kelas akan menyampaikan berbagai peraturan dan tata tertib yang diajukan dalam forum rapat untuk kemudian didiskusikan dengan orang tua dan mendapatkan persetujuan antara pihak sekolah dengan orang tua murid melalui penandatanganan kontrak aturan dan tata tertib kelas atau sekolah. Adapun jenis punishment yang diterima siswa jika melakukan pelanggaran tersebut di antaranya adalah diberikannya teguran lisan atau pemberian surat yang akan ditujukan kepada orang tua murid jika memang anak tersebut sudah tidak dapat lagi dikendalikan oleh guru kelasnya. Pemberian punishment tersebut disesuaikan dengan pelanggaran yang dilakukan siswa. Guru akan memberikan jenis punishment sesuai tingkat pelanggaran.

Selanjutnya, dalam upaya melaksanakan pengawasan atas perencanaan yang sudah dibuat, wali kelas juga senantiasa melakukan pengawasan dan monitoring terkait perkembangan karakter dan nilai religius siswa dengan senantiasa memberikannya pendalaman materi tentang keagamaan. Pengawasan dilakukan melalui pemberian penilaian karakter dari buku keagamaan siswa. Siswa akan dipantau perkembangan religinya mulai dari bentuk hafalan ayat AlQur'an, bacaan dan tata cara shalat yang benar, do'a sehari-hari, hafalan hadits nabi, nama-nama malaikat yang wajib diketahui, dan lain-lain yang termuat dalam kurikulum keagamaan sekolah.

\section{Pembahasan}

\section{Perencanaan Pengelolaan Kelas Rendah di SD Amaliah Ciawi Bogor}

Berkaitan dengan dilakukannya rapat guna pencapaian tujuan dan mengakomodir aspirasi dari semua guru dalam rapat kerja antara yayasan dan sekolah, serta antara guru dan orang tua murid tersebut sesuai dengan pendapatnya Robbins dan Coulter (2012) yang berpendapat bahwa planning involves defining the organization's goals, establishing strategies for achieving those goals, and developing plans to integrate and coordinate work activities. It's concerned with both ends (what) and means (how). Artinya, Perencanaan membahas tentang definisi tujuan organisasi, penetapan strategi untuk mencapai tujuan, dan mengembangkan 
rencana untuk mengintegrasikan dan mengkoordinasikan kegiatan kerja. Ini berkaitan dengan kedua kata (apa) dan cara (bagaimana).

Adapun yang menjadi salah satu hal yang sangat unik dari perencanaan pengelolaan kelas rendah di SD Amaliah Ciawi Bogor adalah ide pertama kali untuk memunculkan sebuah program itu senantiasa muncul dari orang tua murid yang kemudian direalisasikan dalam kegiatan kelas. Rapat orang tua yang kontinu dan per kelas memungkinkan dihadirinya oleh kepala sekolah dan struktural sekolah pada setiap kelas. Peran orang tua murid dalam memberikan kontribusi berupa ide dan pendapat tersebut senantiasa mewarnai proses pembelajaran terutama dalam pengelompokkan kelas rendah di SD Amaliah Ciawi Bogor. Peran orang tua pada SD Amaliah Ciawi Bogor sangat besar dan senantiasa berjalan sinergis dengan program yang sudah dibuat oleh sekolah ataupun kelas. Komunikasi antara orang tua, siswa, dan guru terjalin dengan baik pada setiap saat melalui berbagai media dan perangkat yang sudah disiapkan oleh sekolah dan guru kelas.

Langkah perencanaan yang dilakukan oleh wali kelas pada SD Amaliah sesuai dengan pendapatnya Jones dan George (2009) bahwa planning is a process that managers use to identify and select appropriate goals and courses of action. The three steps in the planning process are: (1) deciding which goals the organization will pursue, (2) deciding what courses of action to adopt to attain those goals, and (3) deciding how to allocate organizational resources to attain those goals. Artinya, perencanaan adalah proses memilih untuk mengidentifikasi dan memilih tujuan yang tepat dan arah tindakan. Tiga langkah dalam proses perencanaan adalah memutuskan (1) tujuan organisasi, (2) apa program tindakan untuk mengadopsi tercapainya tujuan tersebut, dan (3) bagaimana mengalokasikan sumber daya organisasi untuk mencapai tujuan tersebut.
Terkait dengan kemampuan untuk membuat perencanaan (plans) yang baik, maka perencanaan harus senantiasa dimusyawarahkan dalam sebuah tim kerja agar konsep perencanaan tersebut menjadi sesuatu yang mendekati sempurna setelah dilakukan komunikasi atau koordinasi dengan tim. Tanpa disadari proses pembuatan perencanaan pengelolaan kelas yang dilakukan oleh SD Amaliah Ciawi Bogor sebenarnya mengadopsi pendapatnya Robbins dan Coulter (2009) yang menyatakan bahwa planning is a management function that involves defining goals, establishing strategies for achieving those goals, and developing plants to integrate and coordinate activities. Artinya, perencanaan adalah fungsi manajemen yang melibatkan tujuan mendefinisikan, strategi membangun untuk mencapai tujuan tersebut, dan menumbuhkan perkembangan untuk mengintegrasikan dan mengkoordinasikan kegiatan.

Berdasarkan apa yang selalu dilakukan SD Amaliah Ciawi Bogor sebelum membuat sebuah perencanaan yakni senantiasa mengkomunikasikannya melalui sebuah rapat, maka terlihat semakin jelas bahwa pada dasarnya SD Amaliah Ciawi Bogor melakukan tahapan pembuatan tujuan, membuat strategi dan menumbuhkembangkan berbagai perencanaan program melalui koordinasi dalam forum rapat. Oleh sebab itu, dengan proses tersebut, memudahkan sekolah untuk selanjutnya menjalankan atau melaksanakan program sesuai dengan perencanaan.

Selanjutnya, hasil pengamatan di lapangan, jika dilihat berdasarkan waktunya, perencanaan pengelolaan kelas rendah pada SD Amaliah Ciawi Bogor tersebut ada yang dibuat berdasarkan waktu jangka pendek, jangka menengah, dan jangka panjang. Dengan dibuat perencanaan berdasarkan ketiga waktu tersebut, maka akan sangat memudahkan lembaga untuk memperoleh hasil sesuai dengan yang diharapkan.

Konsep penentuan waktu dalam
perencanaan tersebut sesuai dengan
pendapat Carr dan Snyder (2003) yang


mengemukakan bahwa planning is the preparation for the future, thought of as existing on various levels from the top level where overall company planning is done, middle level-intermediate plans, programs, and budgets, schedules, and technical performance targets are planned. Planning levels move from the general to the specific and from long to intermediate time horizons. Artinya, perencanaan adalah persiapan untuk masa depan, dianggap sebagai sesuatu yang ada pada berbagai tingkat dari tingkat atas yang mana perencanaan perusahaan secara keseluruhan dilakukan, tingkat menengah-rencana menengah, program, dan anggaran, jadwal, dan target kinerja teknis yang direncanakan. Tingkat perencanaan bergerak dari umum ke khusus dan dari horizon waktu lama untuk intermediate.

$\begin{array}{crr}\text { Sebelum } & \text { melakukan } & \text { proses } \\ \text { pembelajaran, } & \text { wali kelas } & \text { senantiasa }\end{array}$
melakukan tujuan dari berbagai kegiatan yang akan dilakukan di kelas selama proses pembelajaran berlangsung, untuk selanjutnya melakukan rapat dengan orang tua murid terkait berbagai strategi yang akan dilakukan demi terlaksananya proses pengelolaan kelas yang baik sampai pada satu tahun kemudian. Setelah wali kelas dengan orang tua menyepakati aturan tersebut melalui forum rapat awal tahun baru kemudian wali kelas akan melakukan aksi sesuai hasil kesepakatan tersebut. Langkah tersebut diambil dalam rangka memberikan penjelasan tentang bagaimana sebaiknya guru dan orang tua mensikapi berbagai kegiatan, masalah, dan solusi dalam pemecahan masalahan dalam setiap aktivitas kelas selama tahun pelajaran berlangsung. Dengan kesepakatan antara pihak sekolah dengan orang tua murid dimungkinkan wali kelas akan lebih leluasa dalam mengelola kelas selama proses pembelajaran berlangsung.

Jika peneliti amati, maka konsep perencanaan tersebut juga sesuai dengan pendapat dari Jones dan George (2009) yang mendefinisikan perencanaan sebagai planning is a three-step process: (1) determining an organization's mission and goals, (2) formulating strategy, and (3) implementing strategy. Artinya, perencanaan adalah proses tiga langkah yaitu (1) menentukan misi dan tujuan organisasi, (2) merumuskan strategi, dan (3) menerapkan strategi.

\section{Pengelolaan Suasana Kelas Rendah di SD Amaliah Ciawi Bogor}

Berdasarkan hasil pengamatan dan analisis data yang sudah dilakukan, maka didapatkan hasil bahwa kegiatan pengelolaan kelas rendah melalui pengaturan siswa pada SD Amaliah Ciawi Bogor sesuai dengan pendapatnya Orstein yang dikutip dalam Sunu (2015) yang menyatakan bahwa kepribadian, filsafat, dan gaya mengajar langsung mempengaruhi pendekatan pendidik dalam mengelola kelas.

Selain pengaturan siswa, dalam kegiatan pengelolaan kelas juga dilakukan pengaturan fasilitas kelas. Pengaturan fasilitas kelas tersebut mulai dari pengaturan absen kehadiran siswa yang senantiasa dilakukan pada awal masuk kelas, pengaturan pendistribusian berbagai alat pembelajaran yang pada saat awal masuk sudah diberikan oleh orang tua siswa masing-masing untuk disimpan di loker siswa pada kelas masing-masing. Setelah semua keperluan siswa masuk dalam loker, setiap siswa diperkenankan untuk mengambil semua keperluan barang yang akan digunakannya sendiri selama proses pembelajaran di kelas. Dalam proses pemberian nilai, guru biasanya akan menarsipkan semua penilaian siswa dalam bentuk portofolio siswa yang dipajang di atas kastop kelas supaya memudahkan siswa untuk mengambil dan memasukan kembali jika kemudian ada berkas nilai dan tugas yang bertambah pada hari itu. Dalam hal pemberian tugas di kelas, guru senantiasa menggunakan buku penghubung siswa. Melalui buku penghubung tersebut, orang tua akan mengetahui bahwa putra-putrinya mempunyai tugas atau PR. Begitu pula dengan kegiatan keagamaan, guru kelas juga akan memberikan buku keagamaan kepada semua siswa untuk kemudian disampaikan 
kepada orang tua siswa agar mereka mengetahui tugas hafalan dan target serta batasan mana yang sudah dikuasai oleh putra-putrinya. Dalam hal kegiatan membaca, menulis, dan menghitung pun guru akan memberikan buku membaca kepada semua siswa kelas 1 yang terdiri dari 3 kelas. Siswa-siswi kelas 2 dan 3 tidak diberikan buku membaca tersebut karena biasanya siswa-siswi kelas 2 dan 3 sudah dapat membaca dengan benar.

Pengelolaan fasilitas kelas yang dilakukan oleh guru kelas rendah pada SD Amaliah Ciawi Bogor sesuai dengan pendapatnya UNISA dalam bukunya The Educator as Leader, Manager and Administrator yang disadur dalam bukunya Sunu (2015) yang menyatakan bahwa mengelola lingkungan fisik merupakan cara pendidik mengatur kelas dalam mengkomunikasikan pesan dan harapannya tentang bagaimana ruangan harus digunakan. Berhati-hati menggunakan ruang fisik bisa membuat perbedaan yang cukup besar terhadap perilaku kelas. Sementara itu, Louisell dan Descamp dalam Sunu (2015) berpendapat bahwa ketika mengatur tata letak fisik kelas, pendidik harus tetap mempertimbangkan hal-hal berikut: a) visibilitas, b) aksesibilitas, c) fleksibilitas, d) kenyamanan, dan e) estetika.

Adapun faktor yang dapat mempengaruhi berhasilnya pengelolaan kelas yang baik pada SD Amaliah Ciawi Bogor di antaranya adalah karena faktor fisik, sosio-emosional, dan organisasional. Kondisi fisik mulai dari ruangan kelas yang sesuai dengan peraturan BSNP tentang sarana dan prasarana sangat memungkinkan guru kelas untuk dapat melakukan pengaturan kelas dan tempat duduk yang baik untuk siswanya, serta memungkinkan guru kelas untuk dapat mengatur semua barang siswa dalam loker yang tempat lain yang baik. Kondisi sosioemosional salah satunya terlihat ketika guru mulai melakukan aksinya sebagai leader atau pemimpin di kelasnya. Gaya kepemimpinan guru yang senantiasa demokratis menjadi ciri guru kelas rendah pada SD Amaliah Ciawi Bogor. Kelantangan suara, sikap santun, dan ramah yang senantiasa dilakukan oleh guru kelas menjadi bagian penting dalam diri guru pada sekolah tersebut. Sementara itu, secara organisasional, kondisi kelas rendah pada SD Amaliah Ciawi Bogor terlihat dengan baik pada saat guru sedang memberlakukan kedisiplinan kelas kepada para siswa. Guru kelas akan memberikan reward and punishment kepada setiap siswa sesuai dengan tata tertib yang sudah disepakati sebelumnya pada saat pertama masuk kelas di tahun ajaran baru. Kemudian, pada saat guru sedang menyelesaikan masalah antarsiswa di kelas, guru senantiasa memberikan solusi secara organisatoris dan jelas sehingga membuat semua siswa memahami akan hakikat sebuah permasalahan dan mampu membedakan mana yang benar dan salah dalam kasus tersebut. Hal lain yang dapat dilihat adalah pada saat terjadi masalah dalam diri guru kelas dan kemudian berhalangan hadir ke kelas untuk memberikan materi pembelajaran di kelas, maka kepala sekolah akan segera memberikan mandat kepada guru piket untuk menjadi pengganti guru kelas tersebut. Dalam proses pemberian materi dalam kegiatan pembelajaran di dalam kelas, guru piket tersebut seperti sudah terbiasa masuk kelas rendah dan menjadi guru kelas pada kelas yang guru kelasnya tidak dapat hadir. Selain itu, peneliti juga melihat keadaan yang terorganisir pada saat pelaksanaan kegiatan upacara bendera hari Senin. Semua siswa kelas 2 dan 3 mengikuti kegiatan upacara bendera secara disiplin dan khusu. Meskipun usia anak kelas 2 dan 3 baru sekitar tujuh sampai sembilan tahun, namun mereka sudah mampu menerapkan sifat cinta tanah air yang baik.

Strategi dalam pengelolaan kelas rendah yang dilakukan oleh guru kelas pada SD Amaliah Ciawi Bogor sesuai dengan pendapatnya Van der Horst dan McDonald yang disadur dalam bukunya Sunu (2015) yang menyatakan bahwa suasana kelas berbeda secara luas. Perasaan atau suasana psikologis dan sosial di kelas bisa bervariasi dari yang menarik, ramah dan santai, mengancam, kompetitif, dan tegang. Data 
penelitian menunjukan bahwa sejumlah faktor bisa memengaruhi suasana kelas. Faktor-faktor ini dapat dikelompokkan menjadi empat kelompok di antaranya adalah: a) ekologi-aspek fisik kelas-ruang, furnitur, peralatan, dan lain-lain, b) lingkungan pergaulan-bagian dari ruang kelas yang digambarkan sebagai "perasaan" kelas, c) sistem sosial-aturan formal dan informal yang menuntut hubungan antarpribadi di kelas, dan d) budaya-nilai, keyakinan, sistem, dan norma-norma yang ada di dalam kelas.

Tujuan pengelolaan kelas rendah jelas terlihat dengan baik di SD Amaliah Ciawi Bogor. Hal tersebut disampaikan berdasarkan hasil observasi dan wawancara selama melakukan penelitian didapatkan data bahwa penataan ruang kelas 1, 2, dan 3 pada SD Amaliah Ciawi Bogor tertata dengan baik, mulai dari peletakan berbagai sarana prasarana kelas yang rapi sampai pada pembinaan siswa yang berbeda latar belakang keluarga, budaya, dan sifat masingmasing siswa sehingga memudahkan siswa untuk melakukan proses pembelajaran pada setiap harinya.

\section{Pengawasan Pengelolaan Kelas Rendah pada SD Amaliah Ciawi Bogor}

Kegiatan melakukan monitoring kelas setiap hari yang dilakukan oleh guru kelas pada SD Amaliah Ciawi Bogor tersebut sesuai dengan pendapat Robbins (2009) yang mengatakan bahwa "control is the process of monitoring activities to ensure that they are being accomplished as planned and of correcting any significant deviations"

Selain hal tersebut, evaluasi pengelolaan kelas rendah juga dilakukan melalui pemberian reward and punishment yang diberikan wali kelas kepada siswa. Pemberian penghargaan tersebut diberikan dalam berbagai kegiatan dan aktivitas siswa, mulai dari siswa masuk kelas sampai dengan keluar kelas. Reward yang diberikan mulai dari pemberian ucapan selamat secara lisan, apresiasi mendalam dalam bentuk tepuk tangan, pemberian nilai dan berbagai ikon yang dapat membangkitkan serta senantiasa menumbuhkan rasa percaya diri dan dihargai dengan apa yang sudah dilakukan siswa. Ikon penghargaan tersebut dapat berupa gambar bintang, ikon burung garuda yang merupakan hasil kreasi siswa itu sendiri, serta tanda jempol yang kemudian ditempel dan dikumpulkan dalam madding masing-masing anak di kelas. Adapun punishment biasa dilakukan guru jika ada anak yang belum mampu melakukan peraturan dengan benar atau bahkan melanggar suatu peraturan yang sudah disepakati sebelumnya antara anak, guru dan orang tua pada saat proses pembelajaran berlangsung. Pada setiap tahun ajaran baru akan dimulai, guru kelas akan menyampaikan berbagai peraturan dan tata tertib yang diajukan dalam forum rapat untuk kemudian didiskusikan dengan orang tua dan mendapatkan persetujuan antara pihak sekolah dengan orang tua murid melalui penandatanganan kontrak aturan dan tata tertib kelas atau sekolah. Adapun jenis punishment yang diterima siswa jika melakukan pelanggaran tersebut di antaranya adalah diberikannya teguran lisan atau pemberian surat yang akan ditujukan kepada orang tua murid jika memang anak tersebut sudah tidak dapat lagi dikendalikan oleh guru kelasnya. Pemberian punishment tersebut disesuaikan dengan pelanggaran yang dilakukan siswa. Guru akan memberikan jenis punishment sesuai tingkat pelanggaran.

Konsep pengawasan tersebut sesuai dengan pendapat Schermerhorn (2010) yang mengatakan bahwa "controlling is a process of measuring performance and taking action to ensure desired results". Artinya, pengendalian atau pengawasan adalah proses mengukur kinerja dan mengambil tindakan untuk memastikan hasil yang diinginkan.

Pemberian reward and punishment tersebut menjadi penting dalam proses pembelajaran siswa di kelas. Melalui reward and punishment yang benar siswa dimungkinkan akan mempunyai kedisiplinan yang tinggi, rasa percaya diri, tanggung jawab, dan dapat memahami 
makna kehidupan yang berujung pada pembentukan karakter yang baik. Pembentukan karakter yang baik harus dimulai dari sejak anak mulai belajar pada tahap SD. Sesuai dengan peribahasa yang menyampaikan bahwa masa kanak-kanak usia SD adalah masanya golden eggs.

Selanjutnya, dalam upaya melaksanakan pengawasan atas perencanaan yang sudah dibuat, wali kelas juga senantiasa melakukan pengawasan dan monitoring terkait perkembagan karakter dan nilai religius siswa dengan senantiasa memberikannya pendalaman materi tentang keagamaan. Pengawasan dilakukan melalui pemberian penilaian karakter dari buku keagamaan siswa. Siswa akan dipantau perkembangan religinya mulai dari bentuk hafalan ayat alqur'an, bacaan dan tata cara shalat yang benar, do'a sehari-hari, hafalan hadits nabi, nama-nama malaikat yang wajib diketahui dan lain-lain yang termuat dalam kurikulum keagamaan sekolah.

Guru dengan orang tua akan senantiasa memantau perkembangan keagaaman tersebut setiap hari dan menuliskan berbagai perkembangan dan belum dicapai siswa dalam buku keagamaan masingmasing. Feed back yang baik dari orang tua tentang informasi dan bantuan mereka untuk anaknya mampu menghafal dengan baik sesuai target menjadi literatur dalam pengawasan religi anak.

Kegiatan pengawasan yang melibatkan guru, orang tua, kepala sekolah, dan seluruh stakeholders pendidikan tersebut diatas sesuai dengan pendapat Robbins (2009) yang berpendapat bahwa controlling it is the process of monitoring, comparing, and correcting work performance. All managers should control, even if they think their units are performing as planned, they can't really know how units are performing unless they have evaluated what activities have been done and compared actual performance against the desired standard. Artinya, pengendalian adalah proses memonitor, membandingkan, dan mengoreksi hasil pekerjaan. Semua pemimpin harus mengontrol, meskipun jika mereka berpikir unit-unit sudah melaksanakan sesuai dengan rencana, mereka tidak bisa mengetahui bagaimana hasil kerja setiap unit jika mereka tidak mengevaluasi apakah aktivitas tersebut telah dilaksanakan dan membandingkan hasilnya berlawanan dengan standar yang diinginkan.

Selain itu, guru kelas juga senantiasa memantau berbagai aktivitas siswa selama di kelas mulai dari membuang sampah pada tempatnya, melaksanakan piket-piket kelas, menjaga dan merawat lingkungan sekitar, melaksanakan kebersihan lingkungan kelas, memantau pelaksanaan ibadah seperti shalat dhuha, memantau program 4S (senyum, sapa, salam, dan santun). Hal tersebut dilakukan mulai dari siswa masuk kelas sampai dengan selesai proses pembelajaran dan keluar meninggalkan kelas.

Pengawasan yang dilakukan oleh guru kelas tersebut sebenarnya adalah realisasi dari bentuk pengawasan akademik dan manajerial yang dilakukan SD Amaliah Ciawi Bogor. Hal tersebut sesuai dengan buku kerja pengawas sekolah yang di terbitkan oleh Pusat Pengembangan Tenaga Kependidikan Badan Pengembangan Sumber Daya Manusia Pendidikan dan Penjaminan Mutu Pendidikan Kementerian Pendidikan Nasional (2011) yang mengemukakan bahwa ruang lingkup kepengawasan meliputi kepengawasan akademik dan manajerial. Kepengawasan akademik dan manajerial tersebut tercakup dalam kegiatan penyusunan program pengawasan, pelaksanaan program pengawasan, evaluasi hasil pelaksanaan program pengawasan serta membimbing, dan melatih profesional guru dan atau kepala sekolah.

\section{KESIMPULAN DAN IMPLIKASI}

Perencanaan pengelolaan kelas rendah pada SD Amaliah Ciawi Bogor dimulai dari pembuatan RPP, program tahunan, dan semester sesuai kalender akademik yang sudah disusun oleh sekolah. Dalam berbagai program yang sudah dibuat tersebut tercatat 
secara jelas bagaimana rencana guru dalam melakukan proses pembelajaran selama satu tahun ajaran yang dititikberatkan pada pembentukan karakter siswa yang baik dengan melakukan berbagai program kegiatan keagamaan, dan mendokumentasikan seluruh hasil kegiatan siswa dalam portofolio serta melakukan rencana komunikasi antara guru dengan orang tua siswa melalui buku penghubung. Sementara itu, pengelolaan suasana kelas dilakukan melalui upaya pengaturan siswa dan fasilitas kelas yang baik. Faktor kondisi fisik ruang kelas, sosio-emosional siswa dan kemahiran guru dalam pengorganisasian kelas menjadi kunci terciptanya keberhasilan tujuan pembelajaran yang menyenangkan pada siswa, selanjutnya pengawasan dilakukan melalui monitoring atau supervisi kelas yang setiap hari dilakukan oleh guru kelas kepada semua siswa, untuk kemudian diberikan reward dan punishment dari berbagai kegiatan yang sudah disepakati pada awal masa proses pembelajaran.

\section{DAFTAR PUSTAKA}

Carr HH and CA Snyder. 2003. The management of telecommunications. The McGraw-Hill Companies, North America.

Dirjen PUOD dan Dirjen Dikdasmen. 1996. Pengelolaan kelas, seri peningkatan mutu 2. Depdagri dan Depdikbud, Jakarta.

Djamarah SB. 2006. Guru dan anak didik dalam interaksi edukatif. Rineka Cipta, Jakarta.

Jones GR and JM George. 2009. Comtemporary management. McGraw-Hill Irwin, New York.

Robbins SP and M Coulter. 2009. Management. Pearson Education, New Jersey.

Robbins SP and M Coulter. 2012. Management. Pearson Education Limited, London.

Schermerhorn JR. 2010. Introduction to Management. John Wiley \& Sons (Asia), Hoboken.

Sunu GKA. 2015. Manajemen kelas. Media Akademi, Yogyakarta.

Tim Dosen Jurusan Administrasi Pendidikan. 2010. Pengelolaan pendidikan. Jurusan Administrasi Pendidikan Universitas Pendidikan Indonesia, Bandung. 